\author{
Tomasz Kowalski \\ Wydział Sztuk Pięknych UMK, Toruń
}

\title{
Wygląd utrwalony tradycją \\ - kilka uwag o ochronie konserwatorskiej cudownych wizerunków
}

\section{WPROWADZENIE}

Cudowne wizerunki stały się tematem wielu rozpraw naukowych podejmowanych nie tylko przez teologów lub religioznawców. Pojawiły się również w badaniach szeroko pojętej humanistyki - historii kultury, historii religii, antropologii kulturowej. Ważnym symptomem zainteresowania nimi jest wprowadzenie problematyki wizerunku kultowego do nowoczesnego nurtu studiów nad sztuką w zakresie tzw. antropologii sztuki (antropologii obrazu) ${ }^{1}$. Liczne przykłady różnorakiego funkcjonowania zabytkowych obrazów i figur otaczanych kultem religijnym i związane z nimi wątki problemowe dotykające kwestii ich ochrony otwierają możliwści dla nowych perspektyw badawczych, m.in. rozważań na gruncie teoretyczno-konserwatorskim.

1 Ich czołowym przedstawicielem jest niemiecki badacz Hans Belting. W nurt ten wpisują się także badania Amerykanina Davida Freedberga, a na gruncie polskim prace: Grażyny Jurkowlaniec, Mateusza Kapustki oraz Anety Kramiszewskiej; zob.: Hans Belting, Obraz i kult. Historia obrazu przed epokq sztuki, przekł. Tadeusz Zatorski, Gdańsk 2010; David FreedBerg, Potęga wizerunków. Studia z historii sztuki i teorii oddziaływania, przekł. Ewa KLEKot, Kraków 2005; Grażyna JuRkowlanIEc, Epoka nowożytna wobec średniowiecza. Pamiątki przeszłości, cudowne wizerunki, dzieła sztuki, Wrocław 2008; Mateusz KapustKa, Figura i hostia: o obrazowym przywoływaniu obecności w późnym średniowieczu, Wrocław 2008; Aneta KramiszewskA, Prawdziwie jest to dom Boga i brama do nieba!: opowieść etiologiczna miejsc świętych w zwierciadle sztuki, Lublin 2012. 
Studia poświęcone teoretycznym podstawom działań konserwatorskich mają w Uniwersytecie Mikołaja Kopernika w Toruniu długą tradycję ${ }^{2}$. Prowadzony tu od lat dyskurs naukowy oparty był na analizie współczesnych uwarunkowań działań konserwatorskich, przy jednoczesnym uwzględnieniu historycznych rozważań aksjologicznych Waltera Frodla i Aloisa Riegla, a także idei Heinricha Rickerta (których współczesną przydatność na nowo zweryfikowano). W wyniku dyskusji prowadzonych w gronie historyków myśli konserwatorskiej oraz konserwatorów z Instytutu Zabytkoznawstwa i Konserwatorstwa UMK powstała koncepcja zabytkoznawczej analizy wartościującej, która w zamyśle jej twórców może służyć jako schemat działania przy podejmowaniu decyzji związanych z ingerencją $w$ materialną strukturę każdego obiektu zabytkowego przy okazji przygotowania prac konserwatorskich i restauratorskich. Pomysł ten jest konsekwentnym rozwinięciem myśli Waltera Frodla, który - snując rozważania na temat tworzenia systematyki wartości - wiedział, że choć będą one pewnym uproszczeniem problemów, to podobna generalizacja jest „pierwszym krokiem, który zmuszeni jesteśmy zrobić, aby rozpoznać wszystkie możliwe cechy, jakie wystąpić mogą w zabytku”3. Jak przekonuje Janusz Krawczyk z IZiK UMK, znajomość i umiejętność rozpoznawania wartości tkwiących w obiektach zabytkowych stanowi podstawę warsztatu zawodowego konserwatorát.

\section{Wartość „wyglądu utrwalonego tradycją" w systematyce Waltera Frodla}

Idąc za rieglowskim porównaniem obiektu zabytkowego („pomnika przeszłości") z żywym organizmem (który przeżywa swoją młodość, dojrzałość i starość) $)^{5}$, Walter Frodl uznał, że wartość dawności wynika z procesu dziejowego, w którym analizowany obiekt zabytkowy „uczestniczył”, oraz z zachowanych na nim śladów starości wpływających na jego obecny wygląd i współczesny odbiór: „powierzchnia dzieła sztuki jest czymś żywym. Działanie dzieła sztuki

2 Janusz KRawczyK, Dialog z tradycja w konserwatorstwie-koncepcja zabytkoznawczejanalizy wartościującej, „Acta Universitatis Nicolai Copernici: Zabytkoznawstwo i Konserwatorstwo”, 44, 2013, s. 507-529.

3 Walter Frodl, Pojęcia i kryteria wartościowania zabytków: ich oddziaływanie na praktykę konserwatorska, przekł. Marian ARszyńskI, („Biblioteka Muzealnictwa i Ochrony Zabytków Seria B” 13), Warszawa 1966, s. 9.

4 KraWCZyK 2013, s. 508.

5 Alois Riegl, Nowoczesny kult zabytków. Jego istota i powstanie, przekł. Ryszard Kasperowicz, [w:] Alois Riegl, Georg Dehio i kult zabytków, red. Ryszard Kasperowicz, Warszawa 2006, s. 43. Jak zauważył Janusz Krawczyk, rozważania takie prowadziły do analogii o charakterze egzystencjalnym, gdzie w przedmiotach będących dziełami rąk ludzkich, które niszczały pod wpływem nieubłagalnych sił natury oraz upływającego czasu, upatrywano głębokiej metafory przemijania człowieka i jego - niezależnego od niego - losu, por. KRAwczyK 2013, s. 513. 
jako przedmiotu żywego zależy w pierwszym rzędzie od jego zewnętrznego

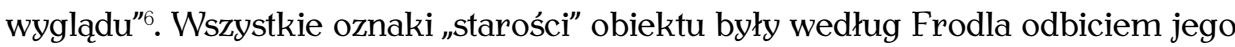
losów i nawet w mocno zniszczonych zabytkach radził on dostrzegać i czcić (!) „cząstkę dzieła sztuki, z którą bezpośrednio stykały się ręce artysty”7. Ponadto, to właśnie fizyczna powierzchnia zabytku, w naturalny sposób narażona na pokrycie patyną i naznaczona śladami upływającego czasu, ma zdaniem badacza przydawać mu dodatkowej wartości artystycznej.

Powierzchnia interesującego nas w kontekście niniejszych rozważań cudownego wizerunku jako frodlowskiego „przedmiotu żywego”, ulegała przekształceniom wynikającym z pobudek religijnych. Zmiana wyglądu („powierzchni dzieła sztuki”) pociągała więc często za sobą zmianę w oddziaływaniu obiektu. Jednak stałym, niezmiennym i konstytuującym jego religijną wartość elementem była owa pierwotna „cząstka” - swoisty rdzeń obiektu, poświadczający jego autentyczność i będący miarą jego roli w praktykach religijnych. Zmiany „powierzchni dzieła sztuki” miały dwojakie podłoże: po pierwsze dostosowywały je do rodzących się nowych religijnych potrzeb (zmiana wyrazu artystycznego obiektu, ikonografii itp.), a po drugie wynikały z konieczności jego odnawiania (obiekty pełniące szczególną rolę w kulcie religijnym z natury rzeczy nie mogły ulegać procesowi zniszczenia, więc podejmowano się zabiegów, które ratowały je przed fizyczną destrukcja). Obie formy działania Frodl definiował jako „czynniki, które znajdują się poza przedmiotem ${ }^{8 \prime}$, i które nie są immanentne (jak wartość naukowa i artystyczna zabytku), lecz związane są z emocjonalnym charakterem odbioru dzieła sztuki i jednocześnie jego oddziaływaniem na otoczenie ${ }^{9}$. Obie prowadzą też do wytworzenia pewnej formy wizualnej, w której Janusz Krawczyk widział frodlowską wartość „wyglądu utrwalonego tradycją”, bardzo ważną - jak się wydaje - z punktu widzenia badań nad cudownymi wizerunkami ${ }^{10}$. Jak pokazuje wiele przykładów, zachodzące $w$ procesie dziejowym przemiany materialnej struktury zabytkowych rzeźb i obrazów pozostających w kulcie, miały charakter działań bardzo specyficznych, silnie powiązanych z aktami religijnymi. Można założyć a priori, że właśnie ze względu na to, iż zabiegi tego typu nie miały charakteru jednostkowego, lecz na ogół wpisywały się w szerszą, osadzoną głęboko w średniowieczu i rozwiniętą w nowożytności tradycję, niosą one za sobą określone wartości kulturowe.

6 Frodl 1966, s. 16.

7 TAMŻE.

8 Frodl 1966, s. 19.

9 Janusz Krawczyk zauważył, że Walter Frodl nie zinterpretował nawarstwień o charakterze kulturowym tak szeroko, jak zrobił to Alois Riegl. Zmiany stanu zachowania „pomnika przeszłości” wynikające z celowego działania człowieka były według Riegla elementem wartości dawności. Frodl natomiast interpretował je jako elementy dość pojemnej wartości symbolu, por. KRAWCZYK 2013, s. 513.

10 Wartość tę badacz zaliczył do wartości estetycznych, ale również proponował rozważenie jej w ramach wartości historyczno-emocjonalnych, por. TAMżE, s. 518-519, 524. 
Utrwalony wygląd (niem. überlieferte Erscheinung) zdaniem Waltera Frodla jest częścią oddziaływania artystycznego, które rozpatrywał on w ramach wartości artystycznej (niem. Kunstwert) ${ }^{11}$. Ów wygląd opisywał jako stan obiektu "do jakiego przyzwyczajono się w czasie długiego okresu” oraz stan, który „utrwalił się w świadomości ogółu”. To również postać obiektu zabytkowego, w jakiej stał się on znany i sławny oraz ta, w jakiej zapisał się on w świadomości społecznej ${ }^{12}$. W przypadku procesu wartościowania zabytków architektury utrwalony wygląd stawał się często ważnym argumentem przy decyzjach dotyczących powojennych rekonstrukcji lub odbudów zniszczonych obiektów, które dla danej społeczności były pewnymi „niezmiennymi punktami oparcia” ich własnej świadomości ${ }^{13}$. Przekładając ten tok myślenia na zabytki plastyki, a szczególnie figury i obrazy otoczone religijną czcią przez wiernych, można pokusić się o zdefiniowanie problemu dotyczącego tej wartości jako pewnych estetycznych wrażeń odbiorców, do których oni się przyzwyczaili. W procesie dziejowym odczucia te znalazły odzwierciedlenie w kopiach i naśladownictwach wytworzonych i trwających w pamięci zbiorowej kolejnych pokoleñ ${ }^{14}$. Tym samym stawały się one swego rodzaju wartością wspólnotową czy wręcz powszechną.

Kwestią wymagającą osobnej refleksji jest status odbiorcy zabytku, do świadomości którego należałoby się odnieść w procesie zabytkoznawczej analizy wartościującej. Tożsamość odbiorców jest główną płaszczyzną odniesień w procesie wartościowania, a należyte jej rozpoznanie i ocena stanowią punkt wyjścia do podjęcia właściwych decyzji o przyszłych losach zabytkowych obiektów. Biorąc za przykład powojenną rekonstrukcję Starego Miasta w Warszawie, za odbiorcę należałoby uznać nie tylko mieszkańców stolicy, ale cały naród polski, dla którego warszawska Starówka - w swej historycznej, przedokupacyjnej postaci - byłaby świadectwem doniosłej roli historycznej miasta i ,jednym ze składników procesu odnajdywania się Polaków we własnej przeszłości”15. Z kolei w przypadku prac konserwatorskich i restauratorskich prowadzonych przy cudownym wizerunku otoczonym kultem religijnym, jego najważniejszym, pierwszorzędnym odbiorcą będzie grupa wiernych, pielęgnujących miejscowy

11 FRODL 1966, s. 13.

12 TAMŻE, s. 23-24.

13 TAMŻE, s. 24.

14 Pojęcia „sfera pamięci zbiorowej” używam tu za Pierre'em Norą, który owe lieux de mémoire tłumaczył jako przestrzenie fizyczne, relacje między zabytkami a szeregiem innych obiektów z ich otoczenia oraz przede wszystkim ich ogólny kontekst społeczny, zob. Pierre NorA, Entre mémoire et histoire, la problématique des lieux, [w:] Les lieux de mémoire, 1, La République, ed. Pierre NoRA, Paris 1984, s. XVII-XLII. Jednak już przed Norą, Walter Frodl sformułował swoje spostrzeżenia, dotyczące „miejsc wyobrażonych i zapamiętanych” oraz reliktów przeszłości będących „nośnikami tożsamości zbiorowej”, zob. KRAwczyK 2013, s. 518-519.

15 Jan Górski, Polityczne i społeczne motywacje odbudowy dzielnicy staromiejskiej, [w:] Warszawskie Stare Miasto: $z$ dziejów odbudowy, red. Emilia Borecka i in., Warszawa 1982, s. 7. 
kult oraz duchownych-kustoszy, sprawujących nad nim opiekę ${ }^{16}$. Interes ogólnonarodowy oraz oczekiwania stosunkowo niewielkiej grupy wiernych podtrzymujących lokalny kult wydają się pozornie nieporównywalne. Warto jednakże wskazać nowy (2007 r.) cel strategii globalnej UNESCO zwany 5C (ang. "fifth C" for "Communities”), który zakłada wzmocnienie bezpośredniego udziału lokalnej społeczności w procesie ochrony związanego z nią dziedzictwa kulturowego i tym samym we wdrażaniu „Konwencji światowego dziedzictwa” ${ }^{17}$. Na gruncie rozważań heritologicznych możemy zatem śmiało uznać, że cudowny wizerunek powinien być traktowany jako element kultury o niezwykle istotnym znaczeniu dla lokalnych społeczności, dla których staje się on nośnikiem ich zbiorowej tożsamości. W myśl założeń strategii „5C” traci znaczenie skala porównawcza odbiorcy obiektu zabytkowego i wówczas na pozór mało istotna wartość „wyglądu utrwalonego tradycją”, niezwykle ważna dla (często niewielkiej) lokalnej społeczności, ma szansę zostać skonfrontowana z innymi - jakby się wydawało - immanentnymi wartościami: autentycznością, integralnością czy wartością historyczno-naukową dzieła sztuki, którym częstokroć jest czczony przez nich wizerunek.

\section{Kultowe nawarstwienia na cudownych wizerunkach}

Kult wizerunków uznawanych za cudowne pociągał za sobą pojawianie się w ich najbliższym otoczeniu rozmaitych przedmiotów. Były to zarówno dowody dewocji wiernych (wota dziękczynne, korony), jak również aplikacje służące szeroko pojętemu przyozdobieniu wizerunku (peruki, sukienki, płaszcze) ${ }^{18}$. Były one nie tylko namacalnym świadectwem wiary i ludowej pobożności, ale także nośnikami nowych znaczeń. Umieszczone w pobliżu wizerunku świadczyły o jego wyjątkowej randze i stawały się materialnym dowodem jego „łaskawości”. Przedmioty te, wiązane $w$ procesie dziejowym $z$ samym cudownym wizerunkiem, z czasem tworzyły jego integralną część i budowały razem z nim pewien

16 Bardzo często figura pełni dla nich funkcję religijną, w niemal całkowitym oderwaniu od jej zabytkowego charakteru.

17 W 2007 roku, decyzją 31 COM 13B, dołączono do czterech celów strategicznych UNESCO ustalonych w „Deklaracji Budapesztańskiej” z 2002, cel piąty - Communities. Tekst decyzji dostępny online: http://whc.unesco.org/en/decisions/5197 (dostęp: 23 III 2017).

18 Na ten temat zob. osobno na kilku przykładach: Tomasz Kowalski, „Tota pulchra es...”. Kultowe dekoracje średniowiecznych figur maryjnych jako przedmiot wartościowania konserwatorskiego, [w:] Clarits et consonantia. Formy, funkcje i znaczenia w sztuce średniowiecza. Księga poświęcona pamięci Kingi Szczepkowskiej-Naliwajek w dziesiąta rocznice śmierci, red. Monika Jakubek-Raczkowska, Juliusz Raczkowski, Toruń-Warszawa 2017, s. 323-346. 
kontekst przestrzenny, nie tylko przechowywany w świadomości wiernych, ale też przenoszony na liczne kopie tworzone w różnych celach: np. nowe wizerunki wykonywane na wzór „oryginału” (por. obraz jasnogórski), obrazki dewocyjne, naśladownictwa ludowe itd.

Na ikonę Madonny z Dzieciątkiem czczoną w klasztorze jasnogórskim już od drugiej połowy XV wieku zaczęto montować dary wotywne, z których w kontekście niniejszych rozważań szczególnie istotne wydają się złotnicze aplikacje $\mathrm{w}$ formie koron. Z pierwszej połowy XVII wieku pochodzi dar przypisywany fundacji króla Władysława IV, z którego wykonano parę koron umieszczonych na obrazie, zwanych w tradycji „koronami władysławowskimi” ${ }^{\prime 9}$. Charakterystyczny kształt insygnium Marii (lekko spłaszczonego bizantyńskiego kamelaukionu) i zawarta na nim ikonografia (Pieta - Maria z siedmioma mieczami boleści, Arma Christi oraz inskrypcje „TIBI S. MARIA” i „TIBI IESU” $)^{20}$ stały się na pewien czas kanonem dla kultowych kopii wizerunku. Korona owa oraz nieco skromniejsza, podobna kształtem korona Dzieciątka, promieniste nimby wokół głów postaci oraz biżuteria, którą przyozdobiono obraz (m.in. w partiach szyi Matki Bożej), budowały zespół dekoracji, które przynajmniej w XVII wieku (zapewne aż do papieskiej koronacji obrazu w 1717 r. nowymi koronami) stanowiły integralną część wizerunku jasnogórskiego. W takiej postaci utrwalał się on w świadomości wiernych. Obraz ten z kolei wspomagały szeroko rozpowszechniane grafiki oraz liczne kopie wizerunku ${ }^{21}$ pojawiające się od XVII wieku w nastawach ołtarzy kościołów Rzeczypospolitej22. Jak zauważyła Ewa Smulikowska,

19 Na temat ozdób wizerunku jasnogórskiego zob.: Ewa SMULIKowska, Korony i sukienki Obrazu Matki Boskiej Częstochowskiej jako przejaw kultu Królowej Korony Polskiej, „Studia Claromontana", 23, 2005, s. 55-88.

${ }^{20}$ Szczegółowy opis ikonograficzny i omówienie programu ideowego korony przedstawiła SMulikowsKa 2005, s. 62-63. Korona przetrwała do dziś jedynie we fragmentach przechowywanych w skarbcu jasnogórskim. Tzw. „koronom władysławowskim” osobny tekst poświęcili Tadeusz Chrzanowski, Marian Kornecki, Program ideowy koron władysławowskich, „Studia Claromontana", 6, 1985, s. 47-62. Warto dodać, że żywa tradycja podtrzymywana po dziś dzień w sanktuarium maryjnym w Topolnie (diec. pelplińska) przekazuje, iż oryginalne korony władysławowskie zostały ok. 1720 r. podarowane przez paulinów jasnogórskich paulinom z Topolna i tam znajdowały się na obrazie Matki Bożej z nastawy ołtarza głównego do dnia kradzieży w marcu 1983 r. (informacja od kustosza sanktuarium w Topolnie, ks. Andrzeja Regenta, odnotowana przez autora 31 VII 2017 r.). Obecnie na topolneńskim obrazie, ponad głową Marii, znajduje się współczesna kopia korony władysławowskiej, w stopniu dużej umowności nawiązująca do swego pierwowzoru (il. 1).

21 Warto zaznaczyć, że w 1621 r. Synod Krakowski, któremu przewodniczył biskup Marcin Szyszkowski, w myśl wprowadzania postanowień Soboru Trydenckiego, zalecił by „obrazy Najświętszej Marii Panny były malowane [...] w taki sposób, w jaki widzimy, że jest namalowana Matka Boska w sławnym miejscu w Częstochowie, lub w temu podobny sposób", zob. Uchwała Synodu Krakowskiego o malarstwie sakralnym, 1621, przel. Grażyna CHILkIEwicz, [w:] Teoretycy, pisarze i artyści o sztuce: 1500-1600, red. Jan BiaŁostocki, Gdańsk 2007, s. 349.

22 Ważniejsze graficzne oraz malarskie naśladownictwa wskazała SMULIKowskA 2005, s. $72-$ 73. Tematowi grafik z historycznymi wizerunkami ikony jasnogórskiej osobny artykuł poświęcił 
kopie ikony jasnogórskiej, odwzorowujące jej aktualny wygląd, były przekazywane przez paulinów znaczniejszym pielgrzymom i tym samym pojawiały się w coraz odleglejszych zakątkach kraju i poza jego granicami. Również malarze cechowi (których pracę ojcowie nadzorowali) w XVII i XVIII wieku licznie sprzedawali pątnikom podobizny cudownego obrazu ${ }^{23}$. Wiele $\mathrm{z}$ nich zachowało się do naszych czasów i samodzielnie pełni funkcje kultowe. Wyjątkowo ciekawym przykładem jest obraz Matki Bożej Częstochowskiej z kościoła parafialnego w Popowie nad Bugiem (diec. płocka), zwany tam obrazem Matki Bożej Popowskiej (datowany na 2. poł. XVII w.), który wiernie odzwierciedla wygląd tzw. „koron władysławowskich” (z uwzględnieniem pełnej, rozbudowanej ikonografii korony Marii) i innych dekoracji przymocowanych niegdyś do jasnogórskiego oryginału ${ }^{24}$ (il. 2). W maryjnym sanktuarium we wsi Koziebrody (w tej samej diecezji) również czczona jest datowana podobnie kopia wizerunku jasnogórskiego, znana jako Matka Boża Koziebrodzka. Także i ona utrwaliła wygląd korony Marii z daru Władysława IV (inną formę nosi korona Dzieciątka)25. Dużą schematyzacją charakteryzują się natomiast malowane korony na obrazie Matki Bożej Częstochowskiej w kościele parafialnym w Ostrowitem (diec. toruńska), pochodzącym - jak wskazuje umieszczona na nim inskrypcja - z 1739 roku ${ }^{26}$. W tym przypadku malarz ograniczył się do nadania koronom kształ-

Ryszard KnapiŃSki, Nieznane grafiki z wizerunkiem Matki Bożej Częstochowskiej, [w:] Zwycięstwo przychodzi przez Maryję, red. Zachariasz S. JABŁoński, Teofil SIUdy, Częstochowa 2006, s. 71-117.

23 SMULIKOWSKa 2005, s. 74.

24 Obraz do 2015 roku całkowicie (z pominięciem partii karnacji postaci) przysłonięty był srebrną koszulką, którą na okazję papieskiej koronacji (23 VIII 2015 r., koronator: metropolita częstochowski abp Wacław Depo) od niego oddzielono i umieszczono na osobnej, ruchomej zasuwie. Wierni mają obecnie możliwość okazjonalnego oglądania cudownego obrazu w oryginalnej postaci (informacja od kustosza sanktuarium w Popowie, ks. Remigiusza Stacherskiego, odnotowana 24 VIII 2015 r.).

25 Andrzej Rojewski, Krzysztof Szwejkowski, $Z$ dziejów kultu Matki Boskiej Koziebrodzkiej, „Studia Płockie”, 21, 1993, s. 141. Niestety w przypadku tego wizerunku przysłaniająca go srebrna koszulka jest z nim na stałe zespolona (niefortunność mocowania wzmaga fakt, że po konserwacji obrazu w 1962 r. koszulkę zainstalowano w dość dużym dystansie od obrazu, co powoduje tworzenie cienia na powierzchni płótna i słabą widoczność partii karnacji Marii i Dzieciątka). Obraz bez koszulki reprodukują: Izabella Galicka, Hanna SygietyńsKa, Powiat sierpecki, (,Katalog Zabytków Sztuki w Polsce" 10/23), Warszawa 1971, fig. 34; oraz: Magdalena LicA-KaczAN, Religijność ludowa czy(li) schrystianizowany światopogląd magiczny, [w:] Stare Mazowsze - przyroda i człowiek, red. Tomasz Kordala, Płock 2006, s. 91.

26 Obraz w zasadzie został odkryty dopiero w $1998 \mathrm{r}$. W trakcie prac konserwatorskich zdjęto wówczas wtórną (prawdopodobnie dwudziestowieczną) warstwę malarską z ówcześnie „obowiązującym" i popularyzowanym wizerunkiem Matki Bożej Częstochowskiej, niewyróżniającym się wysoką klasą artystyczną (informacja od proboszcza parafii Ostrowite, ks. Piotra Kwiatkowskiego, odnotowana przez autora 27 VII 2016 r.); stan obrazu sprzed konserwacji reprodukowany jest w: Marian Dorawa i in., Dekanat golubski, („Diecezja Toruńska, Historia i Teraźniejszość” 7), Toruń 1994, s. 59. Z konserwatorskiego punktu widzenia decyzja o powrocie do pierwotnej formy wizerunku była ze wszech miar słuszna. Podobne „odkrycie” miało niedawno miejsce w 2016 r. w kościele parafialnym w Drzycimiu (diec. pelplińska) - po zdjęciu wtórnych przemalowań z obrazu Matki Bożej 
tu zbliżonego do koron władysławowskich, znacznie uprościł umieszczone na nich motywy dekoracyjne i zrezygnował z pasyjnej ikonografii na koronie Mariii $^{27}$ (il. 3). Mimo syntetyzacji formy, odtworzonej na malarskiej kopii wizerunku, nie ma większej wątpliwości, że inspiracją dla XVIII-wiecznego artysty był dawny, historyczny wygląd cudownego obrazu z Częstochowy, co dodatkowo wzmagają przestylizowane promieniste nimby wokół głów postaci oraz namalowana na ich szyjach biżuteria. Wśród zachowanych do dziś licznych XVII- i XVIII-wiecznych kopii jasnogórskiego obrazu Matki Bożej z Dzieciątkiem można wskazać jeszcze wiele przykładów, w mniejszym bądź większym stopniu odwzorowujące te wyjątkowe aplikacje. Tak zwane „korony władysławowskie” nie przetrwały do naszych czasów, a ikonę jasnogórską wielokrotnie na nowo ozdabiano i zmieniano jej wizualne oddziaływanie. To malowane kopie, utrwalające tradycyjny wygląd obrazu, dają dziś świadectwo jednej z najstarszych, uchwytnych dla badaczy form wizualnych najważniejszego wizerunku cudownego czczonego na ziemiach polskich. Fakt ten powinni mieć zawsze na uwadze decydenci dokonujący analizy wartościującej obrazów, rozpoznawanych jako „kopie obrazu częstochowskiego", z charakterystycznymi, malowanymi aplikacjami $\mathrm{w}$ formie koron.

Warto przyjrzeć się w tym kontekście kilku innym przykładom zabytkowych obiektów o średniowiecznej proweniencji, które do dziś są ośrodkami czci religijnej w sanktuariach erygowanych na prawach diecezjalnych.

Pochodząca z około 1390 roku figura Tronującej Madonny z Dzieciątkiem (il. 4) w kościele oo. Kapucynów w Rywałdzie (diec. toruńska), od XVII wieku otaczana jest ponadregionalną czcią. Jednym $z$ wielu dowodów i świadectw jej kultu były przydane jej w przeszłości złote korony, peruki z naturalnego włosia oraz tekstylne dekoracje szczelnie okrywające rzeźbę (widoczne pozostawały jedynie partie twarzy postaci), całkowicie maskujące jej gotycki charakter stylowy oraz zmieniające jej odbiór ikonograficzny. Dekoracje te stworzyły nową formę wizualną figury - przed oczami wiernych jawiła się postać Madonny z Dzieciątkiem przedstawionej frontalnie en pied, o dość archaicznym wyglądzie. Przydanie figurze zespołu dekoracji było następstwem rozwoju jej kultu - religijny sens tej średniowiecznej rzeźby był nieodłącznie związany z nowożytnymi nawarstwieniami. Dla wiernych wizerunek Madonny Rywałdzkiej jako obiektu czci wyglądał zgoła inaczej niż w pierwotnym zamyśle XIV-wiecznego snycerza. Historyczna forma wizualna tej figury trwała nie tylko w świadomości i zbiorowej pamięci lokalnej społeczności, ale utrwalana była także w rzeźbiar-

Częstochowskiej ujawniono pierwotną „wersję” malowidła ze szczegółowo oddanymi, malowanymi „koronami władysławowskimi”.

27 Wydaje się, że ostrowicki obraz mógł powstać nie jako bezpośrednia kopia jasnogórskiego oryginału, ale był inspirowany np. powszechnymi już wówczas grafikami przedstawiającymi ikonę częstochowską lub innym kultowym naśladownictwem. 
skich i malarskich kopiach (il. 5) oraz na pamiątkowych obrazkach dewocyjnych. Wskażmy choćby na fasadę miejscowego kościoła, gdzie we wnęce nad wejściem głównym, umieszczono w XVIII wieku rokokową drewnianą figurę przedstawiającą Madonnę Rywałdzka, wyrzeźbioną jako stojąca postać z rozszerzającą się ku dołowi suknią nakrytą płaszczem ${ }^{28}$. W podobnej formie wizerunek z Rywałdu został uwieczniony na XIX-wiecznej, powielanej grafice, którą pątnicy zabierali ze sobą jako pamiątkę ${ }^{29}$.

Piętnastowieczna figura Madonny z Dzieciątkiem z Łąk Bratiańskich, przechowywana dziś w bazylice kolegiackiej pw. św. Tomasza Apostoła w Nowym Mieście Lubawskim (diec. toruńska), została w XVIII wieku (zapewne na okazję papieskiej koronacji w 1752 r.) ozdobiona metalowymi aplikacjami. Dekoracja wykonana ze złoconej i srebrzonej, trybowanej blachy przybrała formę rozszerzanego ku dołowi, pozbawionego drapowań, kopulastego płaszcza (il. 6). Wyglądem miał on przypominać tekstylną sukienkę nakrytą rozpiętym od frontu płaszczem z bogato zdobionymi krawędziami z wyłogami. Aplikacja przesłoniła prawie w całości średniowieczny oryginał, z którego widoczne były jedynie partie karnacji Madonny z Dzieciątkiem ${ }^{30}$. Podobnie jak w przypadku kultu w Rywałdzie, na wizerunek Madonny Łq̨kowskiej składała się w niewielkiej części gotycka rzeźba i dominujący nad nią, obudowujący ją, barokowy płaszcz. Ta właśnie forma stała się wzorem dla grafik na dewocyjnych obrazkach oraz dla ludowych naśladownictw, pojawiających się nie tylko na terenie dawnego państwa zakonnego (il. 7$)^{31}$, ale również na nadgranicznych terenach Mazowsza ${ }^{32}$. Wydaje się również, iż swego rodzaju cytatem zaczerpniętym z przystrojonej płaszczem Madonny Łąkowskiej jest obecny wygląd niewielkiej rzeźby Madon-

28 Tadeusz Chrzanowski, Marian Kornecki, Powiat wąbrzeski, („Katalog Zabytków Sztuki w Polsce” 11/19), Warszawa 1967, s. 38. Obecnie umieszczona jest tu kamienna kopia figury. Snycerski oryginał znajduje się w budynku klasztoru.

29 Grafikę tę umieścił w swojej pracy Józef CHocıszewski, Pielgrzymka do ważniejszych miejsc w ziemiach polskich, wsławionych cudownemi obrazami N. Maryi Panny, Poznań 1882, s. 320.

30 Tomasz Kowalski, Wizerunek łaskami słynący jako nośnik wartości kulturowych na przykładzie średniowiecznych rzeźb kultowych w sanktuariach maryjnych w Polsce, praca magisterka napisana w Instytucie Zabytkoznawstwa i Konserwatorstwa UMK pod kierunkiem Moniki Jakubek-Raczkowskiej, [mps], Toruń 2015 (dostęp - Archiwum Zakładu Historii Sztuki Średniowiecznej i Nowożytnej UMK oraz Archiwum Prac Dyplomowych UMK w Toruniu), s. 94.

31 Wskażmy rzeźbę umieszczoną w niszy w górnej części portalu zachodniego kościoła parafialnego w Grucie k. Grudziądza (il. 7). Ryszard Brykowski, Teresa ŻurkowskA, Powiat grudziądzki, („Katalog Zabytków Sztuki w Polsce” 11/7), Warszawa 1974, s. 35 (dla porządku należy dodać, iż autorzy katalogu błędnie zidentyfikowali tę figurę jako przedstawienie Matki Bożej Rywałdzkiej).

32 Niech za przykład posłuży zrekonstruowana na terenie Skansenu w Sierpcu kapliczka ze wsi Umienino Łubki z umieszczoną w niej drewnianą, ludową rzeźbą Madonny Łąkowskiej. Zob. Tomasz Czerwiński, Muzeum Wsi Mazowieckiej. Przewodnik, Sierpc 1996, s. 33-34. Jak zauważył autor, w XIX w. wielu mieszkańców ziemi zawkrzeńskiej pielgrzymowało do Łąk Bratiańskich, zabierając stamtąd figurki Madonny, będące kopiami cudownej figury. 
ny z Dzieciątkiem pochodzącej ze wsi Lipy, a otoczonej obecnie kultem w kościele pw. Nawiedzenia NMP i św. Anny w Lubawie (diec. toruńska). Podobieństwo osiągnięto poprzez umieszczenie na figurze Madonny Lipskiej aplikacji złotniczej w formie szerokiego płaszcza zakrywającego ją od frontu i odsłaniającego jedynie głowy obu postaci ${ }^{33}$ (il. 8).

Ludowe naśladownictwa liczone w setkach kopii umieszczanych w domowych ołtarzykach oraz przydrożnych kapliczkach, powtarzające i utrwalające (raz dość szczegółowo, a innym razem całkiem syntetycznie) kultową formę wizerunku, związane są z XV-wieczną figurą Marii Służebnicy w Świątyni (il. 9) w kościele Bernardynów w Skępem (diec. płocka). W podobny sposób jak Madonna Łąkowska, rzeźba ta została w XVIII wieku dosłownie zakryta metalowymi aplikacjami, budującymi stożkowy płaszcz odsłaniający jedynie twarz i dłonie Marii. Rzeźbione przez twórców ludowych kopie pojawiły się na masową skalę i weszły do dewocyjnego obiegu od połowy XIX wieku (wręcz „zdominowały” one przydrożne kapliczki ziemi dobrzyńskiej, północnego Mazowsza i Kujaw). Powielały one archetypiczny wzór stożkowego korpusu z niewielką ukoronowaną główką i małymi, złożonymi do modlitwy dłońmi ${ }^{34}$ (il. 10). Kwestia fenomenu ludowych naśladownictw Madonny Skępskiej i ich funkcjonowania w kulturze wsi centralnej Polski wykracza jednak poza zakres niniejszych rozważań35.

Nowożytny entourage średniowiecznej figury (lub obrazu) nadawał jej nową formę, budującą z biegiem czasu jej kanoniczny, rozpowszechniony i tradycyjny wygląd. Stawał się on wartością kulturową. Dla zrozumienia religijnej istoty cudownego wizerunku i roli, jaką odgrywał i nadal odgrywa w procesie kształtowania tożsamości wiernych, konieczne jest uwzględnienie całego zestawu przydanych mu historycznie przedmiotów. To one budują kompletny obraz czczonego wizerunku, który trwa w świadomości jako dziedzictwo kultury religijnej.

33 Czczona w Lubawie figura Madonny z Dzieciątkiem (zw. Lipska) ma nietypową formę, ograniczoną w zasadzie do opracowania głów Marii i Jezusa, pozostawiającą resztę korpusu jako nieopracowany kawałek drewna. Wydaje się więc, że figura od początku była przewidziana do uzupełnienia o metalową aplikację, nadającą jej „właściwy” (nawiązujący do łąkowskiego) wygląd, zob. Jerzy DomasŁowski, Matka Boża z Lip, „Nowości” (19 marca 1997), s. 9; Krzysztof Rynkowski, Sanktuarium Matki Boskiej Lipskiej w Lipach k. Lubawy, Pelplin 2000, s. 29-33. Nie można wykluczyć, że pierwotnie figura ozdobiona była sukienką tekstylną, a dopiero z czasem świadomie przywołano obiegową i znaną już wówczas formę „łąkowską” i wykorzystano ją do ozdobienia figurki z Lip.

34 Krystyna PawŁowskA, Miłkowscy - rzeźbiarski ród z ziemi dobrzyńskiej, „Rocznik Muzealny”, 4, 1991, s. 46; Alicja Mironiuk Nikolska, Polska sztuka ludowa, Warszawa 2010, s. 51-53.

35 Ostatnio na ten temat: Justyna PietruszewskA, Matka Boża Skępska. Recepcja i funkcja cudownego wizerunku w sztuce ludowej Mazowsza i Kujaw od XVIII wieku do współczesności, praca magisterska napisana w Instytucie Zabytkoznawstwa i Konserwatorstwa UMK pod kierunkiem Moniki Jakubek-Raczkowskiej, [mps], Toruń 2015 (dostęp - Archiwum Zakładu Historii Sztuki Średniowiecznej i Nowożytnej UMK oraz Archiwum Prac Dyplomowych UMK w Toruniu). 


\section{Współczesne kierunki prac konserwatorskich i restauratorskich przy cudownych wizerunkach}

W procesie dziejowym aplikacje budujące kultową formę cudownego wizerunku często znikały $z$ jego najbliższego otoczenia i były zastępowane innymi. Wynikało to z potrzeby nadania cudownemu obrazowi czy figurze nowej oprawy, bardziej wpisującej się w „gust epoki” (taka sytuacja zaistniała w przypadku wspomnianych „koron władysławowskich” z obrazu jasnogórskiego, które zastąpiono innymi), a niekiedy było następstwem kradzieży lub zniszczenia dawnych aplikacji. Usuwanie ich nie wynikało zatem z troski o stan techniczny wizerunku (nie może nam umknąć fakt, że aplikacje były przecież mechanicznie do niego montowane) lub z zamiaru świadomego wyeksponowania pierwotnej formy obrazu czy figury. Praktyki o takim podłożu zaczęły się pojawiać dopiero w drugiej połowie XX wieku, w dobie rosnącego zainteresowania cudownymi wizerunkami jako elementami materialnej spuścizny artystycznej ziem polskich. Konserwatorski postulat ochrony autentycznej substancji zabytku stawał się przyczyną pozbawiania wielu z nich kultowych nawarstwień. Przeciw działaniom tego typu oponował w latach 70. XX wieku Jan Samek ${ }^{36}$; również Marian Kornecki krytykował zjawisko wzmożonego, wręcz „masowego”, demontażu dekoracji i aplikacji z cudownych wizerunków ${ }^{37}$.

Podobny los spotkał wspomnianą figurę Madonny Rywałdzkiej. Przy okazji prac konserwatorskich przeprowadzonych w latach 70 . XX wieku podjęto decyzję o pobawieniu jej barokowej, tekstylnej sukienki i wyeksponowaniu średniowiecznej formy rzeźbiarskiej ${ }^{38}$. Dokonano w tym przypadku wyboru na rzecz autentycznej formy i wzmocnienia jej wartości historyczno-naukowej (Kornecki nazwał ten zabieg „rewindykacją”

36 Jan SAMEK, Do zagadnienia sukienek $i$ wotów $w$ sztuce polskie epoki baroku (na marginesie komunikatu R. Brykowskiego, „Sukienka - wotum metalowe z Parczewa”), „Polska Sztuka Ludowa”, 4, 1974, s. 244. Badacz podkreślit, że bezceremonialne zdejmowanie sukienek powodowane chęcią ukazania, „często niewyróżniającego się artystycznymi walorami, malowidła” prowadzi do odejścia w zapomnienie, ale również co gorsza - często do „zaginięcia” wielu wysokiej klasy dzieł nowożytnego złotnictwa.

37 Marian Kornecki, Posłowie, [w:] Janusz Stanisław PAsIERB, Ochrona zabytków sztuki kościelnej, przygotował Jerzy ŻMudzıŃskI, („Biblioteka Towarzystwa Opieki nad Zabytkami”), Warszawa 2001, s. $183-184$.

38 Tadeusz Chrzanowski, Marian Kornecki, Nieznane rzeźby gotyckie kręgu pomorskiego, „Rocznik Historii Sztuki”, 8, 1970, s. 313-314. Przed zdjęciem sukienki i szczegółowym rozpoznaniem dzieła uznawano rzeźbę za obiekt o stulecie późniejszy. 
zabytku $\left.{ }^{39}\right)$. Stało się to kosztem osłabienia wartości „wyglądu utrwalonego tradycją", pozostającego w świadomości wiernych. Jak się wydaje, wynikiem kompromisu pomiędzy dwiema sprzecznymi racjami było pozostawienie na figurze tylko jednego elementu z kompletu dawnych nowożytnych dekoracji - dwóch peruk z naturalnego włosia na głowach Marii i Dzieciątka. Zdjęta z Madonny Rywałdzkiej tekstylna sukienka znalazła swoje nowe miejsce w Muzeum Warszawskiej Prowincji Kapucynów w Zakroczymiu (diec. płocka, ok. 180 km od Rywałdu $)^{40}$. Bez wątpienia sytuacja taka nie sprzyja zachowaniu choćby pozorów dawnej „integralności” dzieła, choć intencje muzealizacji i właściwego zabezpieczenia tego cennego obiektu wydają się być słuszne.

Na przeciwnym biegunie można umiejscowić przypadek figury Madonny Łq̨kowskiej z Nowego Miasta Lubawskiego. Forma wizualna tego cudownego przedstawienia spopularyzowana była nie tylko w ludowych naśladownictwach i obrazkach dewocyjnych, ale również na pamiątkowych medalach i medalikach, które przez wieki wybijano (ostatni w 1980 r.). W 2002 roku, z okazji 250. rocznicy koronacji wizerunku, figura przeszła gruntowną konserwację ${ }^{41}$. Wykonano wówczas szczegółową dokumentację rzeźby ukrytej dotąd pod metalowym płaszczem, ale do nastawy głównego ołtarza powróciła ona $z$ całym kompletem aplikacji. Potrzeba eksponowania autentycznej średniowiecznej formy zabytkowej rzeźby została zaspokojona przez wykonanie wiernych kopii, które włączono w różne celebracje - m.in. do tzw. „wodnej procesji” organizowanej od kilku lat na rzece Drwęcy pomiędzy Nowym Miastem Lubawskim a Łąkami Bratiańskimi w święto Narodzenia NMP (8 IX). W obrzędzie tym kopia cudownej figury Madonny z Dzieciątkiem spławiana jest rzeką z pełną asystą (częstokroć z udziałem biskupa diecezjalnego) w towarzystwie wiernych, płynących kajakamił ${ }^{42}$. Kolejne kopie „nieodzianej” figury umieszczono m.in. w kościele Matki Bożej Zwycięskiej i św. Jerzego przy ul. Podgórnej w Toruniu i w kościele św. Marcina w Boleszynie (diec. toruńska). Zatem łąkowski wizerunek, zarówno w formie przystrojonej, jak i oryginalnej, jest popularyzowany i utrwalany w pamięci wiernych. Jest to sytuacja zgoła odmienna niż w Rywałdzie - tutaj obie wartości (wygląd autentyczny oraz tradycyjny) zostały potraktowane jednakowo. Na osobną uwagę zasługuje jednak kwestia

39 Marian KoRNEckI, Granice interwencji i aranżacji konserwatorskiej, „Ochrona Zabytków”, 115, 1976, s. 299.

40 Informacja od br. Tomasza Płonki, kierownika Muzeum Warszawskiej Prowincji Kapucynów w Zakroczymiu, odnotowana przez autora 3 sierpnia $2015 \mathrm{r}$. Wraz z sukienką w muzeum zdeponowano dawne, barokowe korony zdjęte z figury.

41 Dariusz Kunicki, Panno! W łakowskim ukoronowana obrazie..., Toruń 2002, s. 64. Prace przeprowadził ks. Andrzej Kulesza, aktualnie konserwator diecezjalny diecezji toruńskiej.

42 Zob. http://www.nowemiasto.com.pl/ti/figua-drweca.htm (dostęp: 23 III 2017). 
ewentualnego szkodliwego wpływu metalowego płaszcza na materialną strukturę dzieła ${ }^{43}$.

Analogiczny problem związany z wyglądem utrwalonym tradycją zaistniał przy figurze Matki Bożej ze Skępego. W 1954 roku, na rok przed dwusetną rocznicą koronacji figury, przeszła ona kilka zabiegów konserwatorskich; po raz pierwszy od dziesiątek lat oficjalnie zdemontowano metalowe aplikacje. Działanie to odsłoniło nieznany dotąd wiernym, gotycki wizerunek ${ }^{44}$. Ze względu na duże zniszczenia spowodowane montażem aplikacji do rzeźby (po gwoździach pozostało ok. 40 otworów ${ }^{45}$ ), zapadła decyzja, by zamiast złotniczego płaszcza zamontować na figurze haftowany płaszcz tekstylny. Cztery dekady później, po kolejnej konserwacji w 1996 roku, figurę przez trzy lata eksponowano całkowicie pozbawioną dekoracji, w jej oryginalnej średniowiecznej, autentycznej formie. Widok odsłoniętej rzeźby nie zyskał jednak aprobaty wiernych, którzy przyzwyczajeni byli do znanej od dwustu lat „koronacyjnej” formy. Na ich usilne prośby, wśród których pojawiały się oskarżenia, że „figurka została podmieniona”, wypracowano ciekawy kompromis. Uszyto lekki, tekstylny płaszcz, formą upodabniający się do dawnego płaszcza blaszanego, jednak z rozpiętym frontem, odsłaniającym snycerską substancję, gotycki kontrapost i układ draperii szat Marii ${ }^{46}$. Osiemnastowieczny płaszcz ze srebrnej blachy został zdeponowany

43 Przez konserwującego figurę w 2002 r. ks. Andrzeja Kuleszę zostałem poinformowany w lutym 2015 r., że figura pod metalowym płaszczem zachowana była w doskonałym stanie i nie brano pod uwagę opcji pozbawienia jej dekoracji.

44 Ks. Antoni Dmochowski, inwentaryzujący w dwudziestoleciu międzywojennym zabytki diecezji płockiej, oglądał skępską figurę bez dekoracji. Na łamach publikowanego w prasie cyklu „Z teki inwentaryzacyjnej Mazowsza Płockiego” zanotował: „Bez korony i płaszcza, tych luźno i niezdarnie prp. w XVII w. [sic!] przyczepionych dekoracyj metalowych jest to niewielki [...] posążek rzeźbiony w drzewie lipowem...”. I dalej: „Posążek jest jeszcze dość dobrze zachowany, jedynie złożone na piersiach rączki są nadłamane skutkiem ciężaru zawieszonego na nich metalowego płaszcza”, zob. Aleksander Dмochowski, Z teki inwentaryzacyjnej Mazowsza Płockiego: Posag M. B. Skępskiej, „Życie Mazowsza”, 3, 1935, s. 84-86.

45 Metalowy płaszcz Madonny Skępskiej, przechowywany w skarbcu klasztornym w Skępem, składa się z trzech elementów przesłaniających figurę jedynie od frontu, przybitych niegdyś do rzeźby za pomocą wielu gwoździ (otwory zachowały się na niemal wszystkich elementach). Dwie główne jego części wykonane z pozłoconej srebrnej blachy mają kształt rozszerzających się ku dołowi trapezów, nieco wygiętych, wspólnie formujących się przestrzennie w kształt stożka (choć jest to tylko wizualne złudzenie). Trzeci fragment z płaskiej blachy, odbiegający starannością wykonania i rodzajem umieszczonej na nim dekoracji, służył wypełnieniu wolnej przestrzeni tworzącej się między dwoma głównymi elementami płaszcza.

46 Krystyna PawŁowska, Skępe. Sanktuarium Matki Bożej Skępskiej, Pani Mazowsza i Kujaw przy klasztorze Ojców Bernardynów (OFM), [w:] U Maryi stóp: sanktuaria Kujaw i ziemi dobrzyńskiej, red. Piotr Nowakowski, Krystyna PawŁowska, Włocławek 2011, s. 175-176. Dało to wiernym impuls do utożsamienia figury z Matka Bożą Brzemienna (sic!), co zostało zaaprobowane przez kustoszy skępskiego sanktuarium i w dużym stopniu przyczyniło się do wzrostu popularności skępskiego kultu i wzrastającej liczby wiernych przybywających do kościoła w uroczystość Narodzenia NMP. W kwietniu 2015 r., z okazji zbliżającej się 260. rocznicy koronacji cudownej figury, 
w klasztornym skarbcu. Krzyżujące się racje konserwatorskie, z jednej strony podyktowane pierwotną formą snycerską rzeźby, a z drugiej strony niezwykle silnie oddziałujące na tradycyjny wygląd wizerunku, wymagały w Skępem lat prób, by można było osiągnąć należny kompromis. Wprawdzie udało się przy użyciu innego nośnika zachować pozory wartości wyglądu utrwalonego tradycją, lecz poskutkowało to po raz kolejny w historii przesunięciem akcentów kultowych: z XVIII-wiecznej królewskości Marii w stronę jej brzemienności. Bez większego znaczenia dla kultu (zarówno dawniej, jak i współcześnie) pozostaje pierwotna ikonografia figury, niezwiązana ani z macierzyństwem Matki Bożej, ani jej przywilejem jako Królowej nieba i ziemi.

\section{Podsumowanie}

Z punktu widzenia współczesnej teorii konserwatorskiej (a szczególnie jej subdyscypliny podejmującej temat dziedzictwa, tzw. heritologii), nowożytne przekształcenia wizualnej formy cudownych wizerunków odbierały im autentyczność oraz zacierały ich wartość historyczno-naukową. Nie możemy jednak pochopnie oskarżać nowożytnych decydentów o celowe naruszanie lub świadome ukrywanie średniowiecznych, pierwotnych struktur tych obiektów. „Upiększające" działania miały przecież głębokie podłoże religijne. Inaczej do kwestii nowożytnych nawarstwień na średniowiecznych wizerunkach pochodzono w XX wieku. Naukowa świadomość naruszenia średniowiecznej struktury rzeźb za sprawą nowożytnych przekształceń, skutkowała pozbawionymi głębszej refleksji próbami powrotu do „stanu pierwotnego”. Tymczasem usunięcie sukienki lub innej wotywnej aplikacji staje się aktem wtórnego odarcia kultowego dzieła z jego emocjonalnych wartości, co z kolei grozi stopniową utratą jego znaczenia w zbiorowej świadomości wiernych, a w skrajnych przypadkach nawet pozbawieniem takiego obiektu dawnego sensu religijnego.

Usuwanie na stałe dowodów kultu, nawarstwionych w procesie dziejowym na cudownych wizerunkach jest działaniem, którego - jak się wydaje - należy unikać. Otoczona czcią wiernych figura lub obraz, wraz ze wszystkimi przydanymi jej przedmiotami, wspólnie stanowią całość, którą należy rozumieć jako "wizerunek kultowy”. Niesie on konkretną, często unikalną formę wizualną, utrwalaną z biegiem czasu w tradycji za pomocą różnych nośników i zapisywaną w ludzkiej świadomości. Każda, nawet najdrobniejsza decyzja, związana $z$ ingerencją $w$ strukturę tych wyjątkowych obiektów, powinna być zawsze po-

biskup płocki oficjalnym dekretem zatwierdził kościół Zwiastowania NMP w Skępem jako „Sanktuarium Diecezjalne Najświętszej Maryi Panny Skępskiej, Matki Bożej Brzemiennej, Królowej Mazowsza i Kujaw", zob. http://bernardyniskepe.com/index.php/dekret (dostęp: 23 III 2017). 
przedzona konstruktywną dyskusją i konfrontacją racji decydentów - przedstawicieli różnych dyscyplin, z każdorazowym uwzględnieniem tych czynników, które miały niegdyś - i będą mieć w przyszłości - wpływ na ich dalsze, właściwe, niezmienne funkcjonowanie.

\section{Tomasz Kowalski}

Faculty of Fine Arts, Nicolaus Copernicus University in Toruń

\section{Traditional appearance \\ - a few remarks on protection of miraculous images}

This article analyzes the cultural value of the "traditional appearance" of an artwork on the basis of a few selected examples of Polish miraculous images. According to Walter Frodl's systematization this value is considered a part of the artistic influence of historic art. This text is an attempt to indicate the important role played by traditional appearance in the process of evaluating artefacts (especially those which form an element of social identity), which takes place before the process of conservation. 


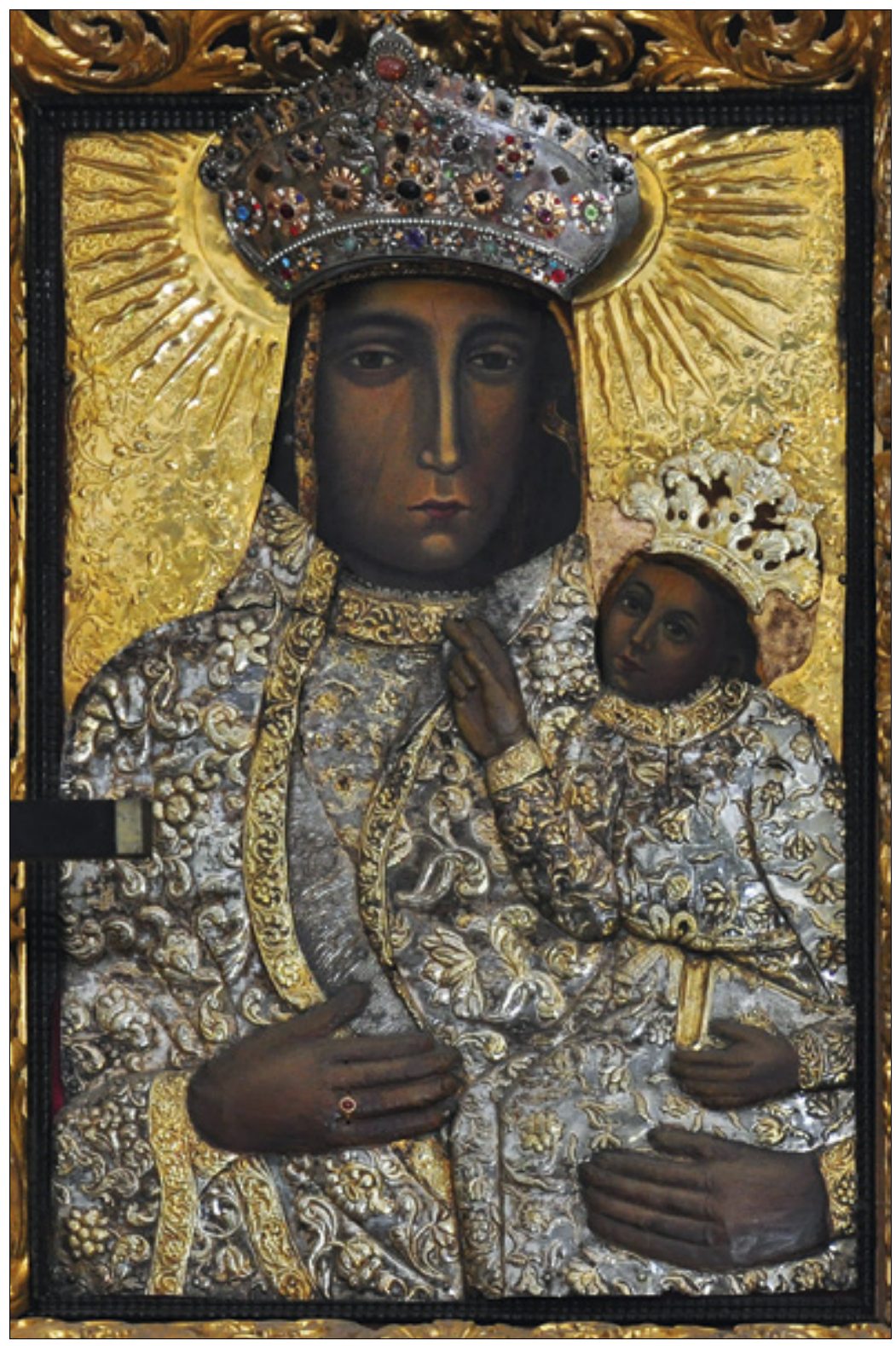

Il. 1. Topolno (diec. pelplińska), kościół par. pw. Nawiedzenia NMP, ołtarz główny, obraz Matki Bożej Częstochowskiej. Fot. T. Kowalski, 2017 


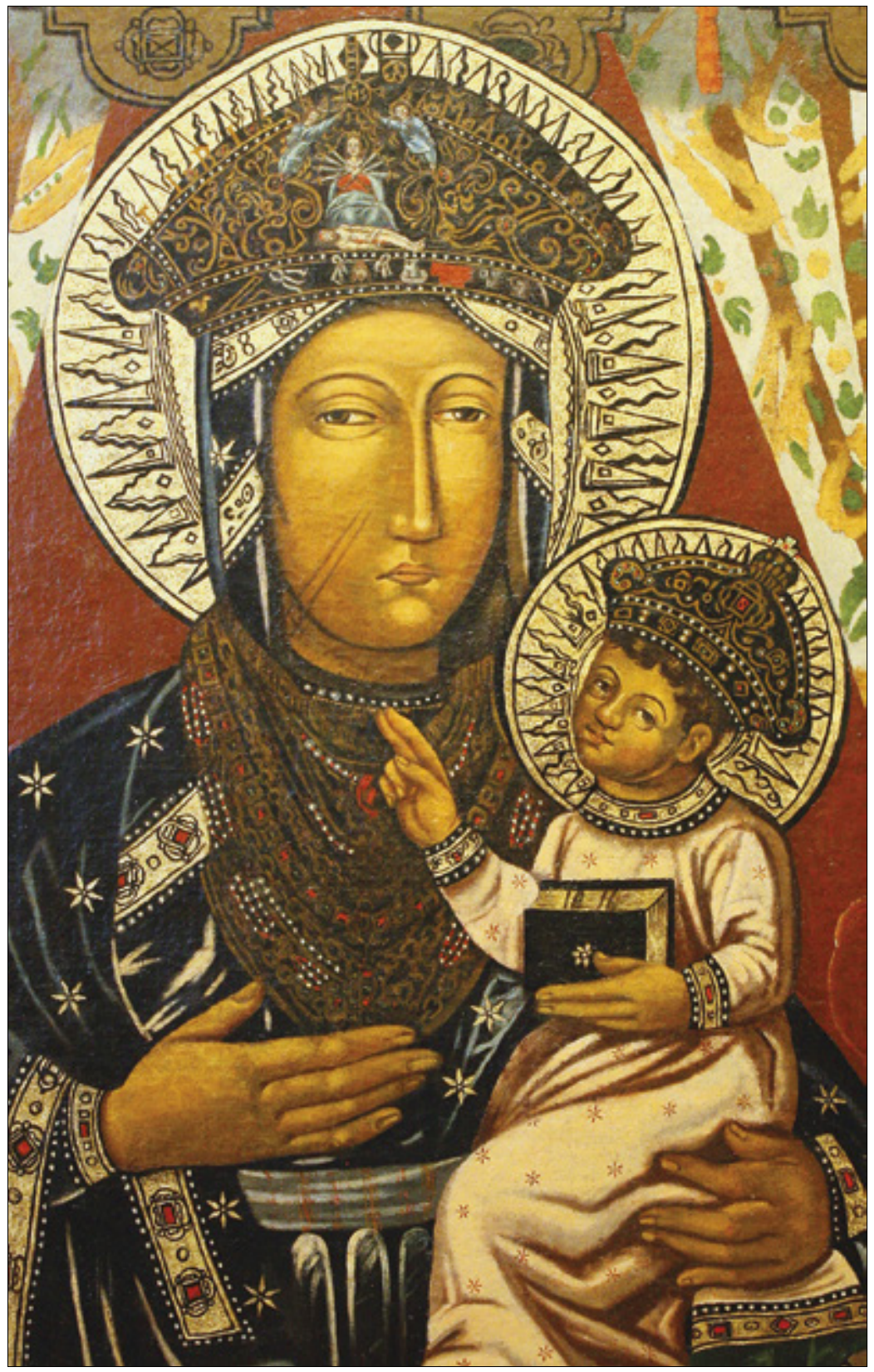

Il. 2. Popowo (diec. płocka), kościół par. pw. Narodzenia NMP, ołtarz główny, obraz Matki Bożej Częstochowskiej, zwany obrazem Matki Bożej Popowskiej. Fot. ze zbiorów parafii, 2015 


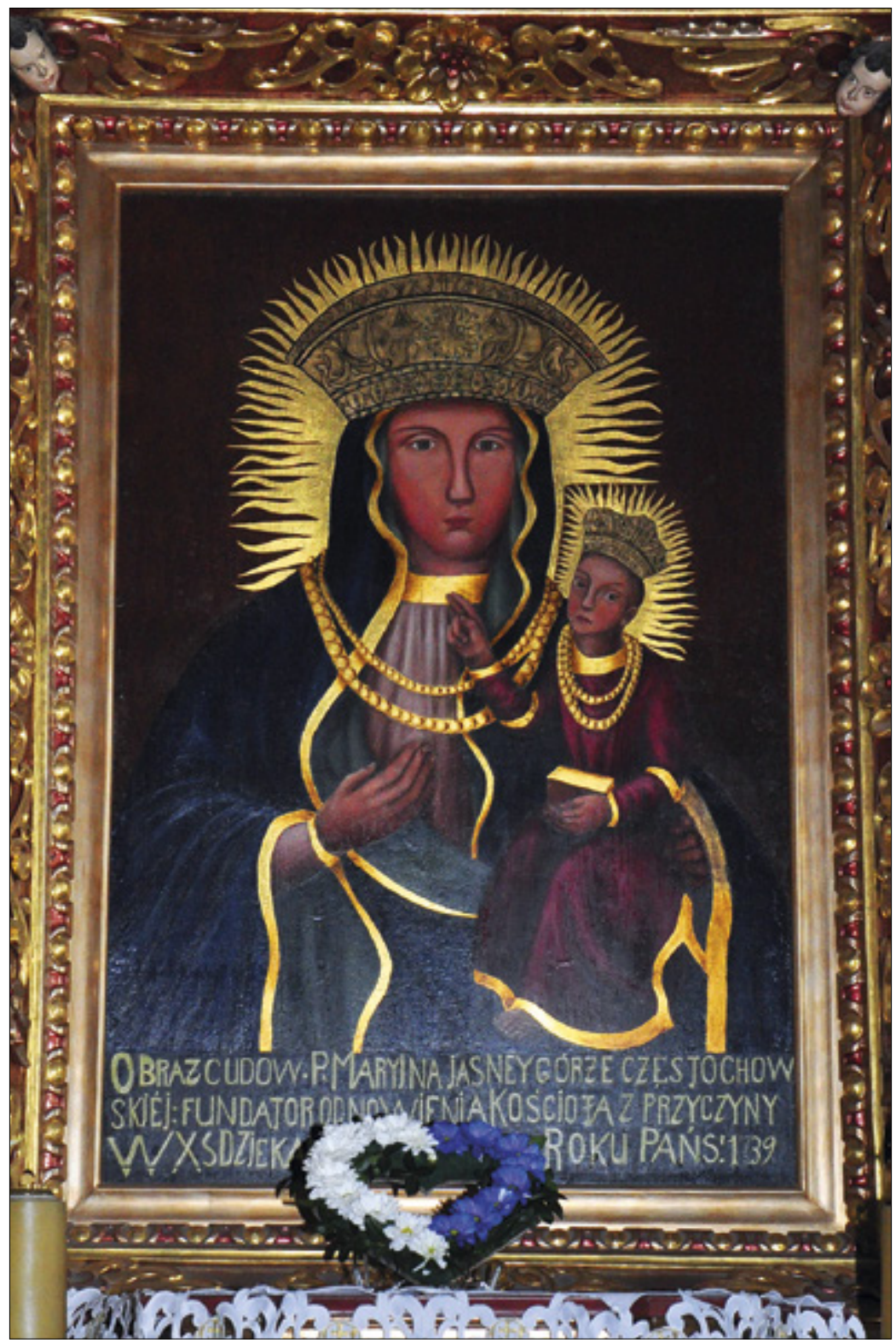

Il. 3. Ostrowite (diec. toruńska), kościół par. pw. św. Marii Magdaleny, ołtarz główny, obraz Matki Bożej Częstochowskiej. Fot. T. Kowalski, 2016 


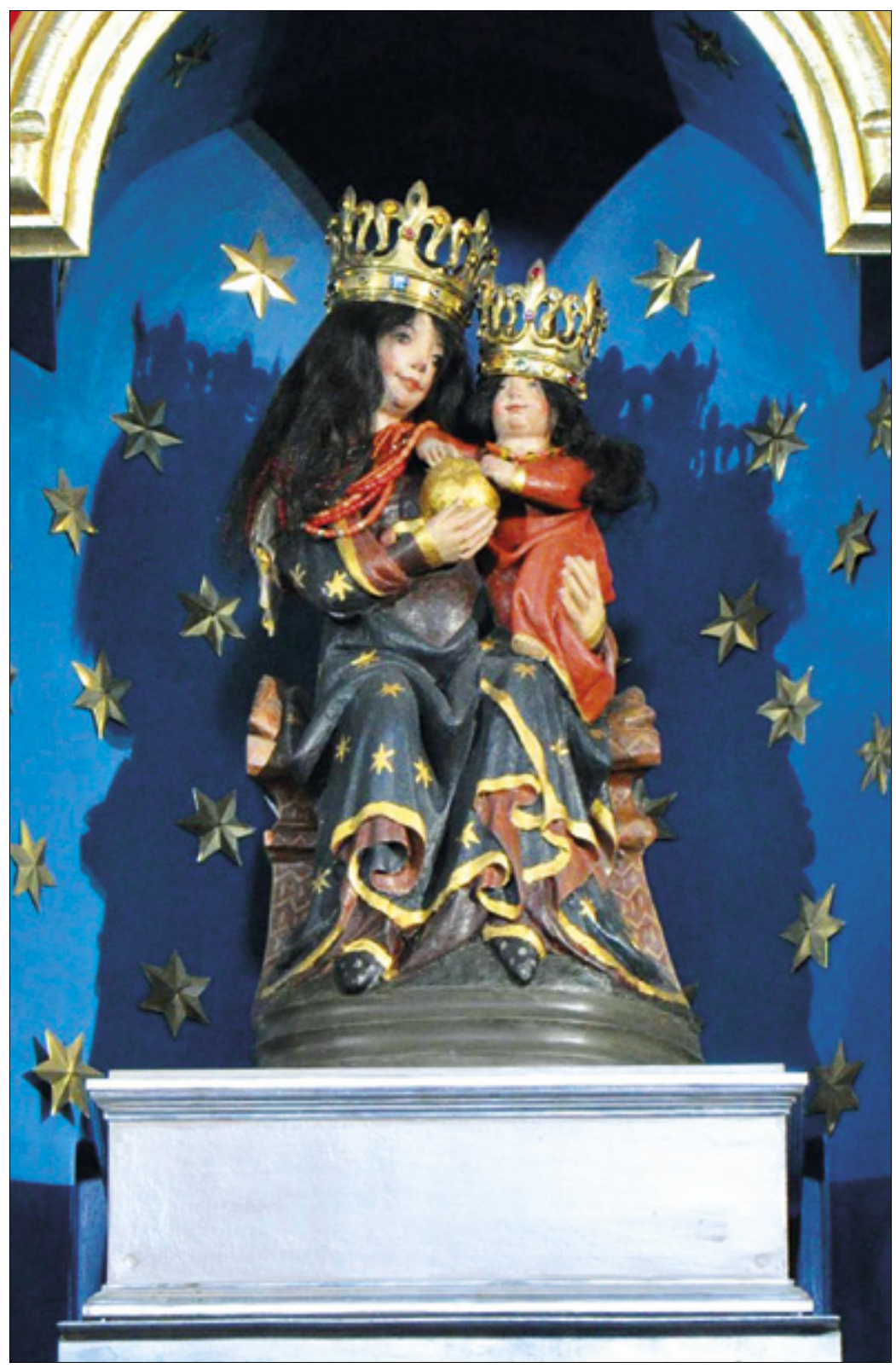

Il. 4. RywaŁd (diec. toruńska), kościół par. pw. św. Sebastiana (Kapucynów), ołtarz główny, figura Tronującej Madonny z Dzieciątkiem, zwana Madonną Rywałdzką. Fot. T. Kowalski, 2017 


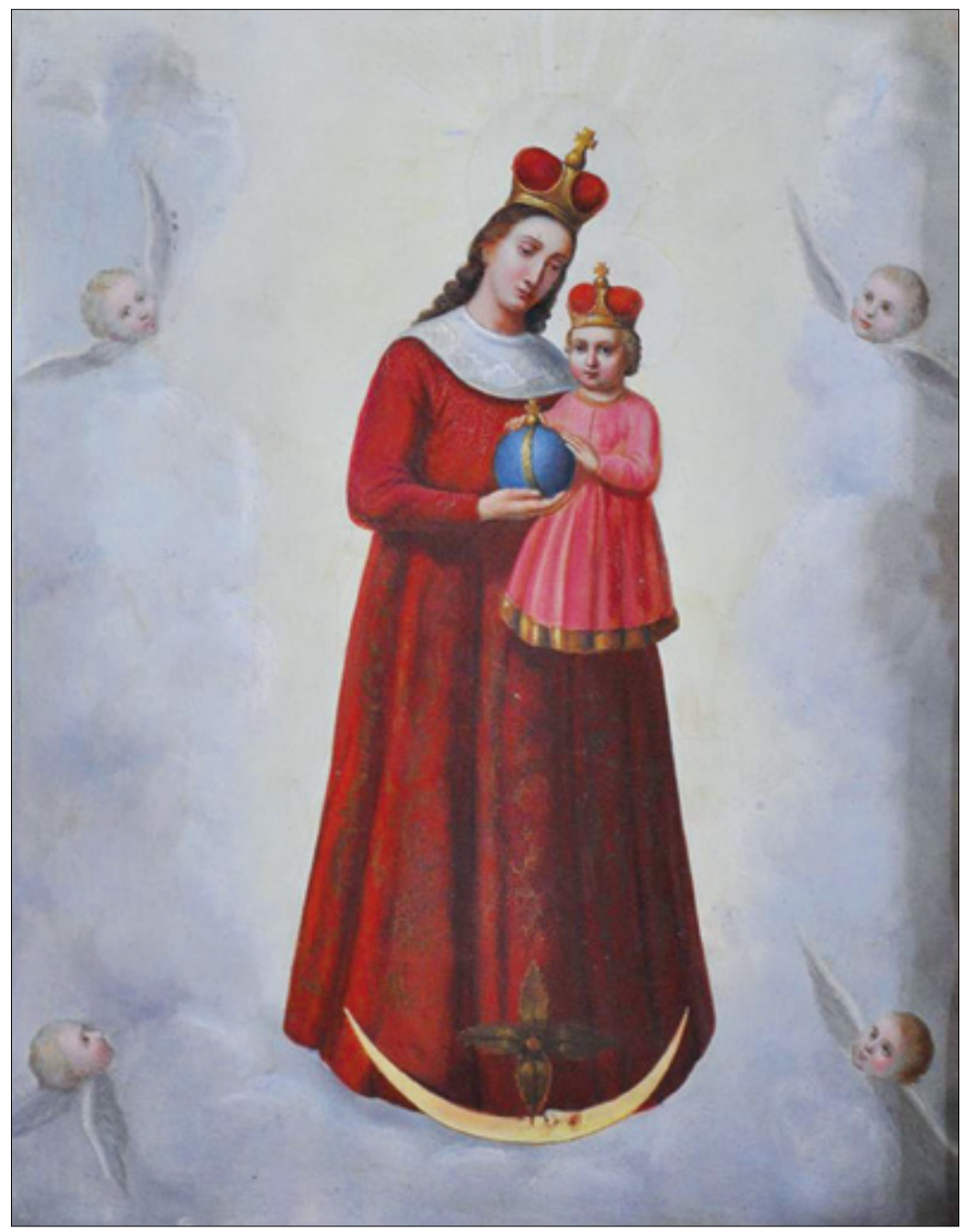

Il. 5. RYwaŁD (diec. toruńska), kościół par. pw. św. Sebastiana (Kapucynów), feretron z obrazem Madonny Rywałdzkiej. Fot. T. Kowalski, 2017 


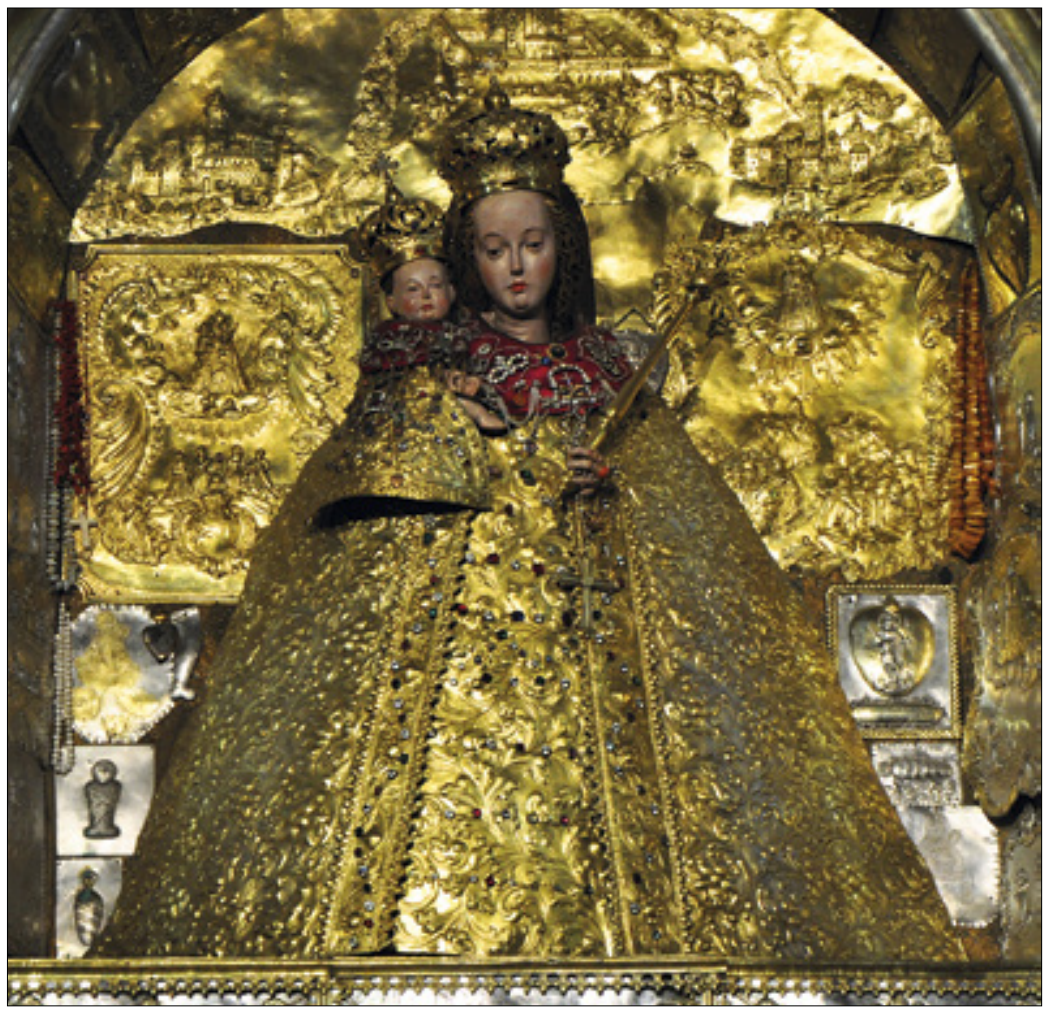

Il. 6. NowE Miasto Lubawskie (diec. toruńska), bazylika kolegiacka pw. św. Tomasza, ołtarz główny, figura Madonny z Dzieciątkiem, zwana Madonną Łąkowską. Fot. T. Kowalski, 2016 


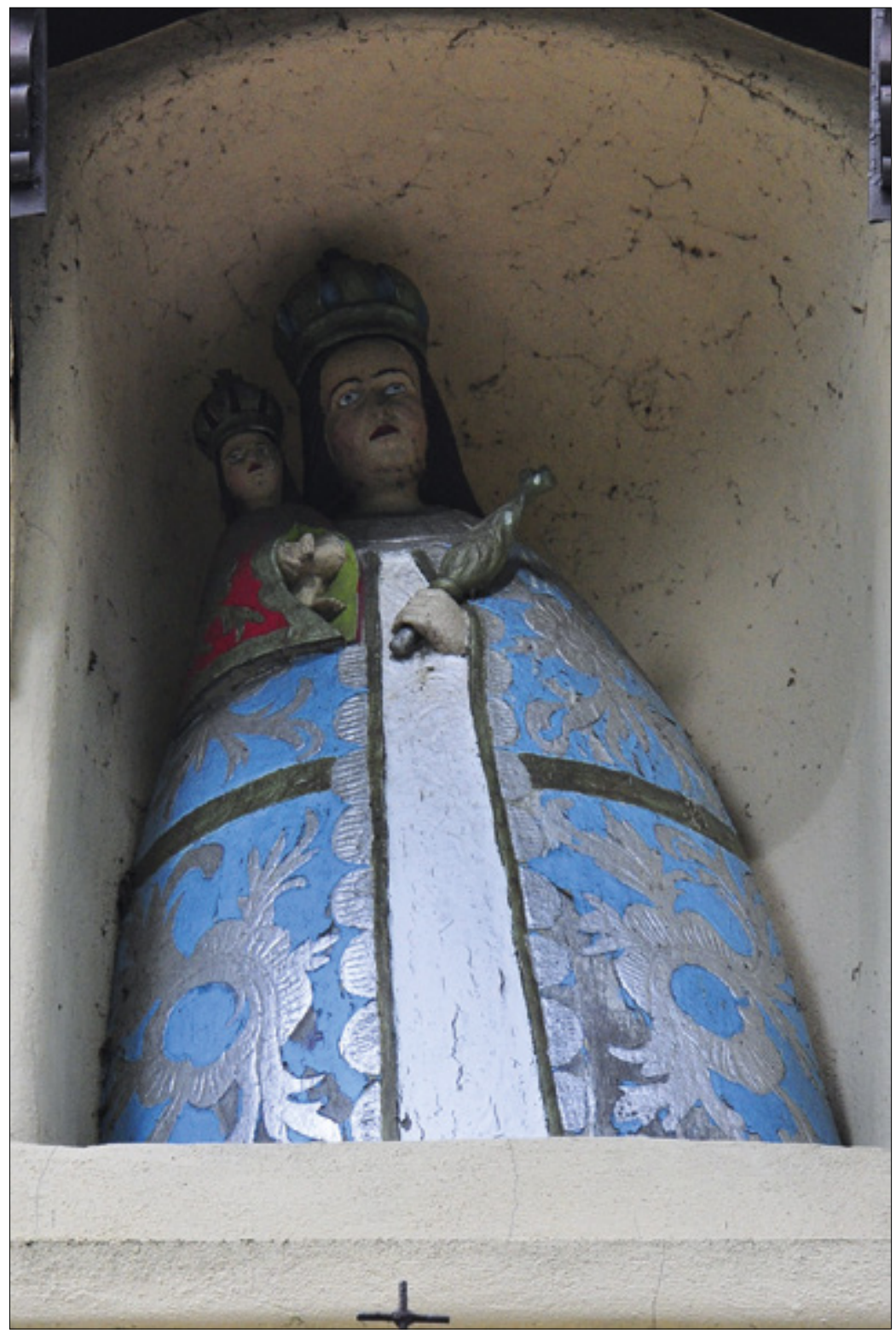

Il. 7. GRUTA (diec. toruńska), kościół par. pw. Wniebowzięcia NMP, portal zachodni, figura Madonny Łąkowskiej. Fot. T. Kowalski, 2016 


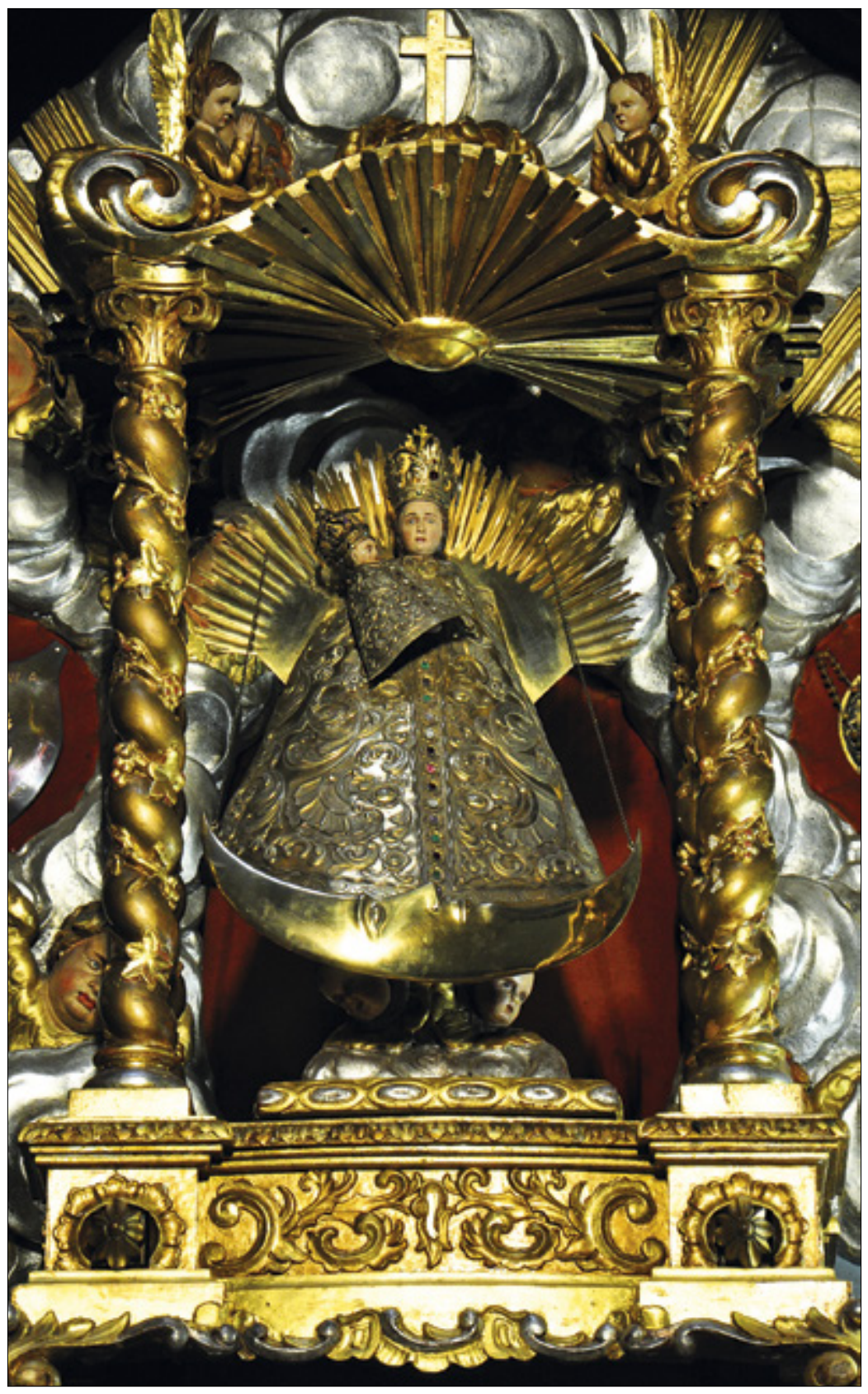

Il. 8. Lubawa (diec. toruńska), kościół par. pw. Nawiedzenia NMP, kaplica Mortęskich, figura Madonny z Dzieciątkiem, zwana Madonną Lipską. Fot. T. Kowalski, 2016 
Wygląd utrwalony tradycją - kilka uwag o ochronie konserwatorskiej cudownych wizerunków

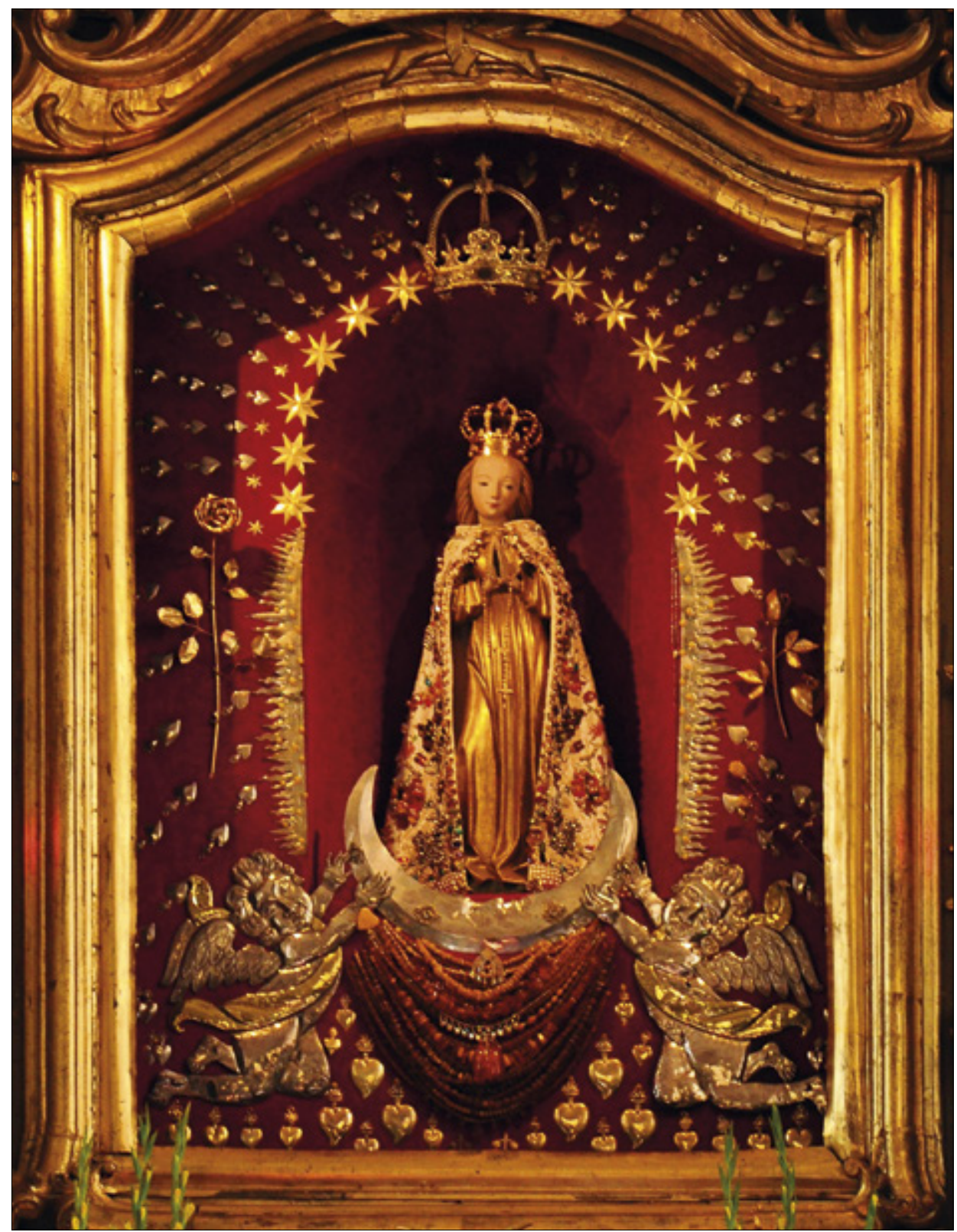

Il. 9. SKĘPE (diec. płocka), kościół par. pw. Zwiastowania NMP (Bernardynów), ołtarz główny, figura Marii Służebnicy w Świątyni, zwana Matką Bożą Skępską. Fot. T. Kowalski, 2015 


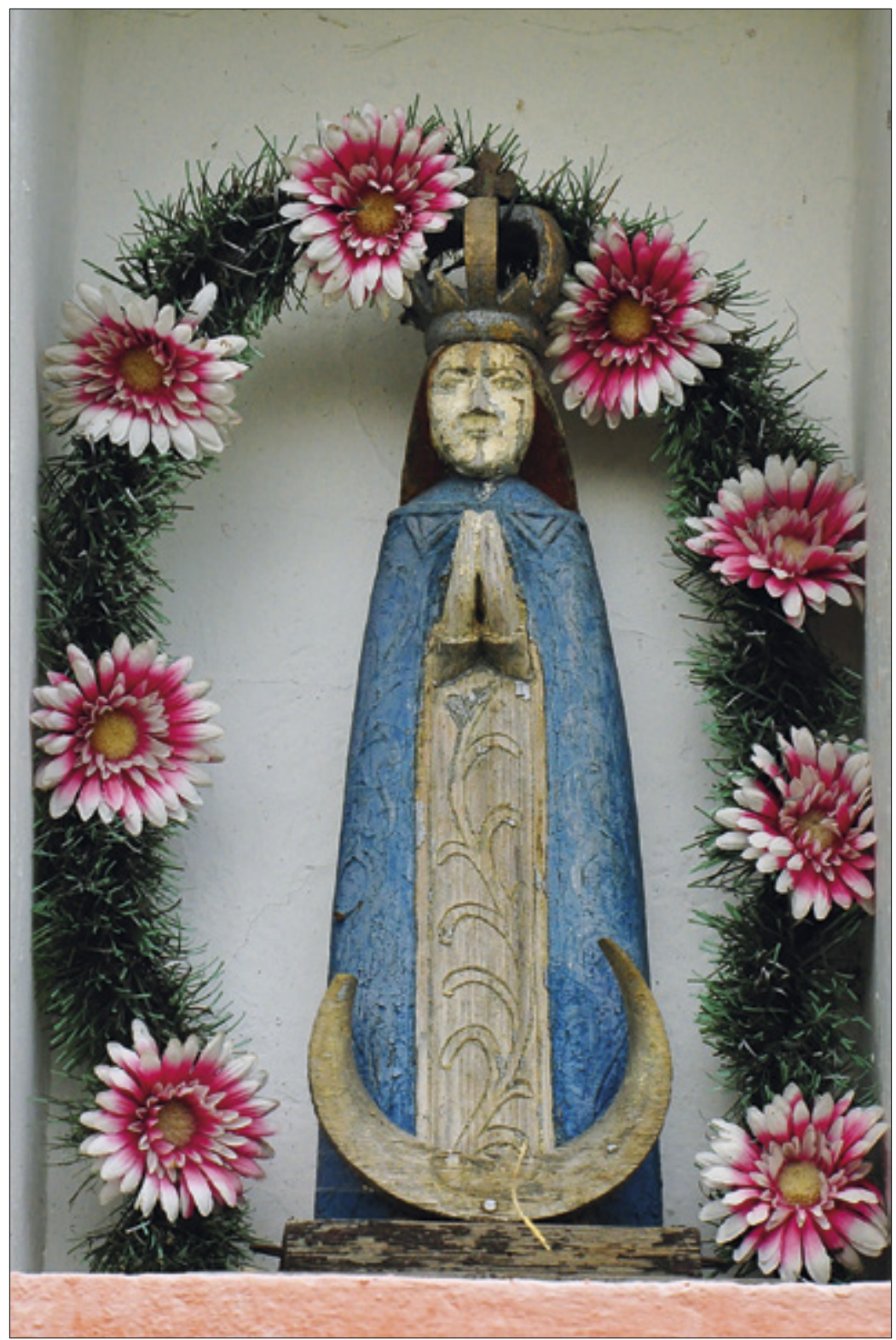

Il. 10. Malanowo Stare (diec. płocka), kapliczka przydrożna z figurką Matki Bożej Skępskiej. Fot. T. Kowalski, 2015 